Article

\title{
Centipede KCNQ Inhibitor SsTx Also Targets $K_{V} 1.3$
}

\author{
Canwei Du ${ }^{1}$, Jiameng $\mathrm{Li}^{1}$, Zicheng Shao ${ }^{1}$, James Mwangi ${ }^{2,3}$, Runjia Xu ${ }^{1}$, Huiwen Tian ${ }^{1}$, \\ Guoxiang Mo ${ }^{1}$, Ren Lai ${ }^{1,2,4, *}$ and Shilong Yang ${ }^{2,4, *}$ \\ 1 College of Life Sciences, Nanjing Agricultural University, Nanjing 210095, Jiangsu, China; \\ ducw1992@163.com (C.D.); 2017116055@njau.edu.cn (J.L.); 2016116042@njau.edu.cn (Z.S.); \\ 2016116040@njau.edu.cn (R.X.); 2017116051@njau.edu.cn (H.T.); mgx@njau.edu.cn (G.M.) \\ 2 Key Laboratory of Animal Models and Human Disease Mechanisms of Chinese Academy of \\ Sciences/Yunnan Province, Kunming Institute of Zoology, Kunming 650223, Yunnan, China; \\ mwangij1124@yahoo.com \\ 3 University of Chinese Academy of Sciences, Beijing 100009, China \\ 4 Sino-African Joint Research Center, Chinese Academy of Science, Wuhan 430074, Hubei, China \\ * Correspondence: rlai72@njau.edu.cn (R.L.); yangsl@mail.kiz.ac.cn (S.Y.)
}

Received: 27 December 2018; Accepted: 27 January 2019; Published: 1 February 2019

check for updates

\begin{abstract}
It was recently discovered that Ssm Spooky Toxin (SsTx) with 53 residues serves as a key killer factor in red-headed centipede's venom arsenal, due to its potent blockage of the widely expressed KCNQ channels to simultaneously and efficiently disrupt cardiovascular, respiratory, muscular, and nervous systems, suggesting that SsTx is a basic compound for centipedes' defense and predation. Here, we show that SsTx also inhibits $\mathrm{K}_{\mathrm{V}} 1.3$ channel, which would amplify the broad-spectrum disruptive effect of blocking $\mathrm{K}_{\mathrm{V}} 7$ channels. Interestingly, residue R12 in SsTx extends into the selectivity filter to block $\mathrm{K}_{\mathrm{V}} 7.4$, however, residue $\mathrm{K} 11$ in SsTx replaces this ploy when toxin binds on $\mathrm{K}_{\mathrm{V}}$ 1.3. Both SsTx and its mutant SsTx_R12A inhibit cytokines production in T cells without affecting the level of $K_{V} 1.3$ expression. The results further suggest that SsTx is a key molecule for defense and predation in the centipedes' venoms and it evolves efficient strategy to disturb multiple physiological targets.
\end{abstract}

Keywords: Centipede; SsTx; $\mathrm{K}_{\mathrm{V}} 7 ; \mathrm{K}_{\mathrm{V}} 1.3$; toxin

Key Contribution: The study identifies the key amino acids for SsTx inhibition on $\mathrm{K}_{\mathrm{V}} 1.3$ channel, which is different from that on $\mathrm{K}_{\mathrm{V}} 7.4$ and shows the inhibition on $\mathrm{K}_{\mathrm{V}} 1.3$ is important in suppressing cytokines secretion in $\mathrm{T}$ cells.

\section{Introduction}

With over 3000 species, centipedes, arthropods of the class Chilopoda are widely distributed in both tropical and subtropical regions. Their first pair of legs have been modified into strong mandibles and venomous fangs called forcipules that play a critical role in defense and predation [1]. Centipede stings occur frequently in areas, such as Hawaii, Brazil, Australia, Taiwan, and Japan [2], evoking an issue of social health care. Centipede toxins are composite mixtures, which are responsible for both local and systemic reactions. Recently, we have identified and characterized several peptide toxins from centipede venom and established they act on ion channels that are associated with pain and inflammation [3-7]. For example, a centipede toxin (RhTx) causes intense local pain by targeting the heat activation machinery of nociceptor TRPV1 (transient receptor potential cation channel subfamily V member 1) channel [4]. We also revealed the molecular basis of cardiovascular, respiratory, muscular, and nervous system's dysfunction due to centipede bites by the identification of Ssm Spooky Toxin (SsTx). It targets KCNQ channels (voltage-gated potassium channel family 7) to exhibit potent lethal 
toxicity by causing severe vessels and respiratory disorders or seizures. Mechanically, SsTx binds to $\mathrm{K}_{\mathrm{V}} 7$ channels tightly, due to the fact that residue $\mathrm{K} 13$ in SsTx anchors the toxin to the outer pore region of $\mathrm{K}_{\mathrm{V}} 7$ channels and residue R12 in SsTx extends into the selectivity filter to block the channels [8]. Therefore, SsTx shows physiological and pathological importance in understanding the efficiency in prey capture and clinical reports after centipede envenomation. In the present study, we established that SsTx also inhibited $\mathrm{K}_{\mathrm{V}} 1.3$ that have been reported to be an important target for autoimmune diseases [9-11]. Through the construction of toxin mutants, we found that SsTx used different side chains to target $\mathrm{K}_{\mathrm{V}} 1.3$, which allowed us to modify them towards specifically targeting $\mathrm{K}_{\mathrm{V}} 1.3$ channel in human T cells. Furthermore, SsTx and its mutant suppressed Tem-effector cells proliferation and cytokine production in $\mathrm{T}$ cells.

\section{Results}

\subsection{SsTx Inhibits $K_{V} 1.3$}

As described in our previous work [8], centipede prey on animals via SsTx inhibiting the $\mathrm{K}_{\mathrm{V}} 7.4$. SsTx consists of 53 amino acids refolded by two intracellular disulfide bonds (Figure 1A). Surprisingly, we found that SsTx toxin also inhibited $K_{V} 1.3$. As illustrated in Figure 1A, SsTx potently inhibited $\mathrm{K}_{\mathrm{V}} 1.3$ currents, with an $\mathrm{IC}_{50}$ value of $5.26 \mu \mathrm{M}$ (Figure 1B). As a pore blocker, SsTx inhibited $\mathrm{K}_{\mathrm{V}} 1.3$ channel in a voltage-dependent manner (Figure 1C), similar to the inhibition of $K_{V}$ 7.4. Taken together, our results, which are consistent with a previous report [12], suggest that the $\beta \alpha \beta \beta$-type toxins have a higher affinity for $K_{V} 7$ and $K_{V} 1.3$ channels. The fact that SsTx shows no effect on Slo1 channel implies that the binding surface of the scorpion toxin charybdotoxin may have sophisticatedly evolved to use a different mechanism to inhibit Slo1 channel [13-15].
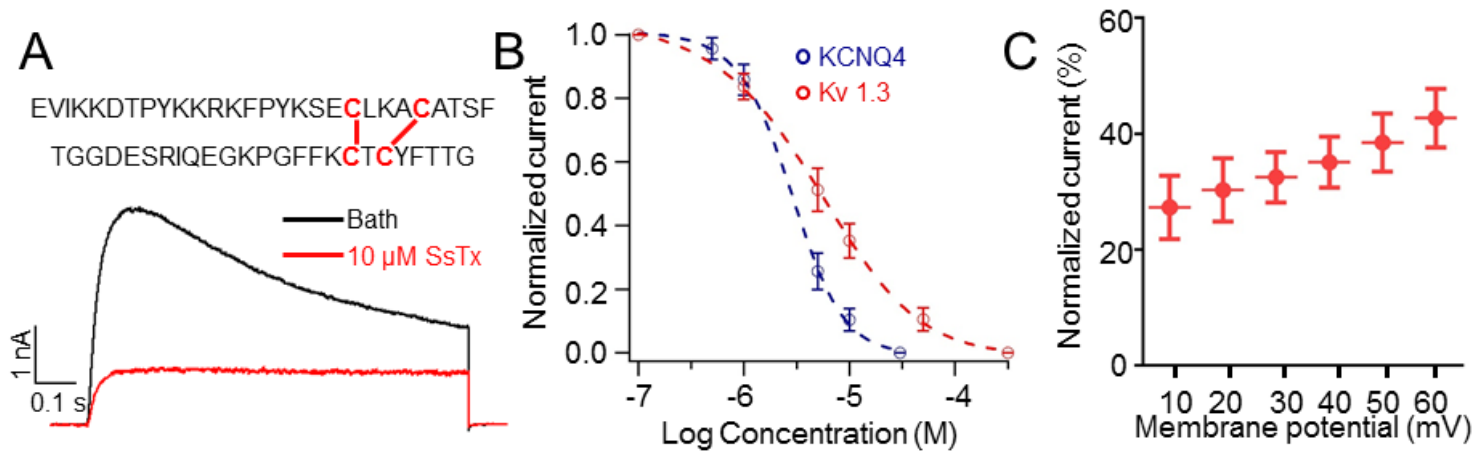

Figure 1. The effect of Ssm Spooky Toxin (SsTx) on $K_{V} 1.3$. (A) $K_{V} 1.3$ currents were inhibited by $10 \mu \mathrm{M}$ SsTx. The black and red traces represent bath solution and solution containing $10 \mu \mathrm{M} \mathrm{SsTx}$, respectively. The upper insert shows the sequence of SsTx and the cysteine residues are presented in red color. (B) Concentration-response curves displaying the inhibition of SsTx on $K_{V} 7.4$ and $K_{V} 1.3$. Data were fitted with a Hill equation. The $\mathrm{IC}_{50}$ values are $2.80 \pm 0.23 \mu \mathrm{M}$ for $\mathrm{K}_{\mathrm{V}} 7.4(n=5$ cells $)$ and $5.26 \pm 0.56 \mu \mathrm{M}$ for $\mathrm{K}_{\mathrm{V}} 1.3\left(n=10\right.$ cells). (C) The relationship between the inhibitory percentage of $10 \mu \mathrm{M}$ SsTx on $\mathrm{K}_{\mathrm{V}} 1.3$ and the test pulses. The cells were held at $-80 \mathrm{mV}(n=4-6$ cells).

\subsection{K11 and $\mathrm{K} 13$ in SsTx Are Crucial for Inhibiting $K_{V} 1.3$}

Toxins with multiple functions have been widely utilized to probe the structure-function relationship of ion channels [16,17]. Given that SsTx targets both $\mathrm{K}_{\mathrm{V}} 1.3$ and $\mathrm{K}_{\mathrm{V}} 7$ channels, we studied the key residues for their bio-activity on $\mathrm{K}_{\mathrm{V}} 1.3$ and $\mathrm{K}_{\mathrm{V}} 7$ channels. Our previous results demonstrate that there are two direct interactions between SsTx and $K_{V} 7.4$ : The side chain of K13 on the toxin anchors it to the outer pore region of $\mathrm{K}_{\mathrm{V}} 7.4$, and the side chain of R12 extends into the selectivity filter (Figure 2A). Because blockage of $\mathrm{K}_{\mathrm{V}} 7$ channels is considered to be toxic, such information may direct our functional efforts to modify this native toxin and acquire a more selective $\mathrm{K}_{\mathrm{V}} 1.3$ inhibitor by mutagenesis. To test whether these residues are also critical for SsTx interaction with $\mathrm{K}_{V} 1.3$ channel, 
we generated point mutations at these sites. These mutant toxins exhibited typical structural features (Figure 2B). Using alanine substitution, we found that the affinity of mutant SsTx_R12A for $\mathrm{K}_{\mathrm{V}} 1.3$ was almost entirely intact (Figure 2C,F). In contrast, the $\mathrm{IC}_{50}$ value of SsTx_K13A mutant increased by more than 100-fold for $\mathrm{K}_{\mathrm{V}} 1.3$, suggesting that K13 on SsTx predominantly affects its binding affinity to $K_{V} 1.3$ (Figure 2D,F). Next, we wondered whether there was another amino acid that specifically mediates the interaction between SsTx and $\mathrm{K}_{\mathrm{V}} 1.3$. We found that the $\mathrm{IC}_{50}$ value of mutant SsTx_K11A increased by more than 100-fold for $\mathrm{K}_{\mathrm{V}} 1.3$ (Figure 2E,F), suggesting the lysine residue at position K11 provides the key side chain that anchors the toxin specifically onto $\mathrm{K}_{\mathrm{V}} 1.3$ rather than $\mathrm{K}_{\mathrm{V}} 7.4$. Therefore, the toxin mutant SsTx_R12A exhibits selectivity on $\mathrm{K}_{V} 1.3$, which is a likely suitable inhibitor for our future studies.
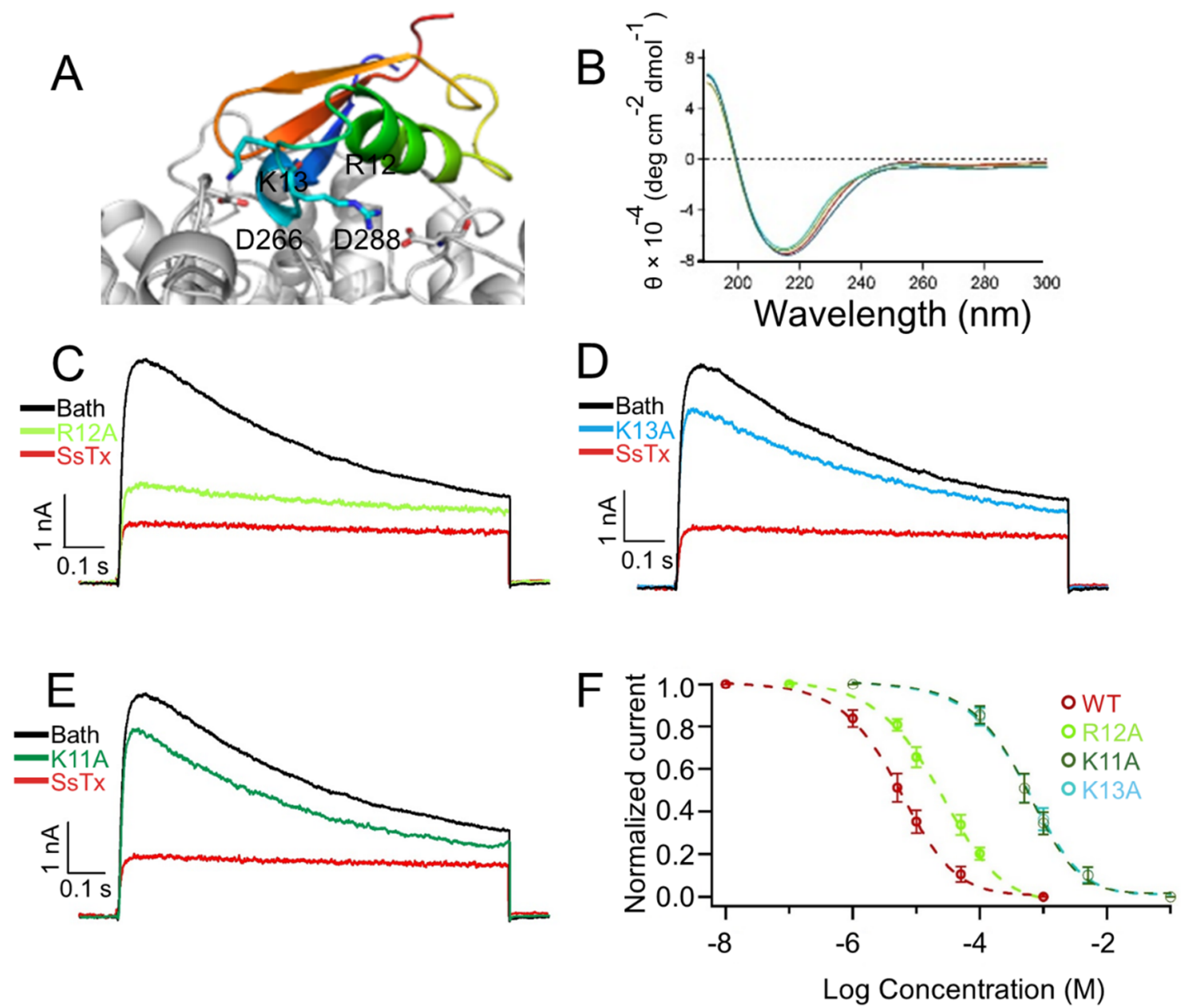

Figure 2. The residues on SsTx altered subtype-selectivity. (A) Molecular docking of SsTx onto KV7.4. The side chains of R12/K13 in SsTx and D266/D288 in KV7.4 are shown. (B) CD (circular dichroism) spectra of SsTx and mutants exhibited no significant difference. (C-E) Representative $\mathrm{K}_{\mathrm{V}} 1.3$ currents were inhibited by $10 \mu \mathrm{M}$ SsTx_R12A (C), SsTx_K13A (D) and SsTx_K11A (E). (F) Dose-response curves displaying the inhibition of SsTx_R12A, SsTx_K13A and SsTx_K11A on $\mathrm{K}_{\mathrm{V}} 1.3$, respectively. The $\mathrm{IC}_{50}$ values are $22.23 \pm 0.22 \mu \mathrm{M}$ for SsTx_R12A ( $n=5$ cells), $526.1 \pm 0.48 \mu \mathrm{M}$ for SsTx_K13A ( $n=5$ cells), and $507.0 \pm 0.61 \mu \mathrm{M}$ for SsTx_K11A $(n=5$ cells), respectively.

\subsection{SsTx and SsTx_R12A Suppress Proliferation of Human T Cells without Affecting the Expression of $K_{V} 1.3$}

The $\mathrm{K}_{\mathrm{V}} 1.3$ channel is expressed abundantly in the immune cell, and it is a target for curing autoimmune diseases. Some molecular compounds [18] and peptides [19] have been used as probes to explore the relationship between $K_{V} 1.3$ and autoimmune diseases. For example, SHK-186, the special 
$\mathrm{K}_{\mathrm{V}} 1.3$ inhibitor, suppresses $\mathrm{T}$ cell proliferation without affecting the level of $\mathrm{K}_{\mathrm{V}} 1.3$ expression [20]. Here, we isolated the Tem (Effective Memory T)-effector cells from peripheral blood mononuclear cells (Figure $3 \mathrm{~A}, \mathrm{~B}$ ). By losing its inhibitory activity to $\mathrm{K}_{\mathrm{V}} 7.4$ but retaining substantial affinity for $\mathrm{K}_{\mathrm{V}} 1.3$, it suggests the mutant SsTx_R12A, after modification, provides a potential therapeutic agent for autoimmune diseases. Additionally, we found both SsTx and SsTx_R12A suppressed Tem-effector cell proliferation in a concentration-dependent manner (Figure 3D) without affecting $\mathrm{K}_{\mathrm{V}} 1.3$ expression even at a concentration of $100 \mu \mathrm{M}$ (Figure 3E). Taken together, our results demonstrated that SsTx and mutant SsTx_R12A potently blocked $K_{V} 1.3$ in human T cells, leading to suppression of cell proliferation.
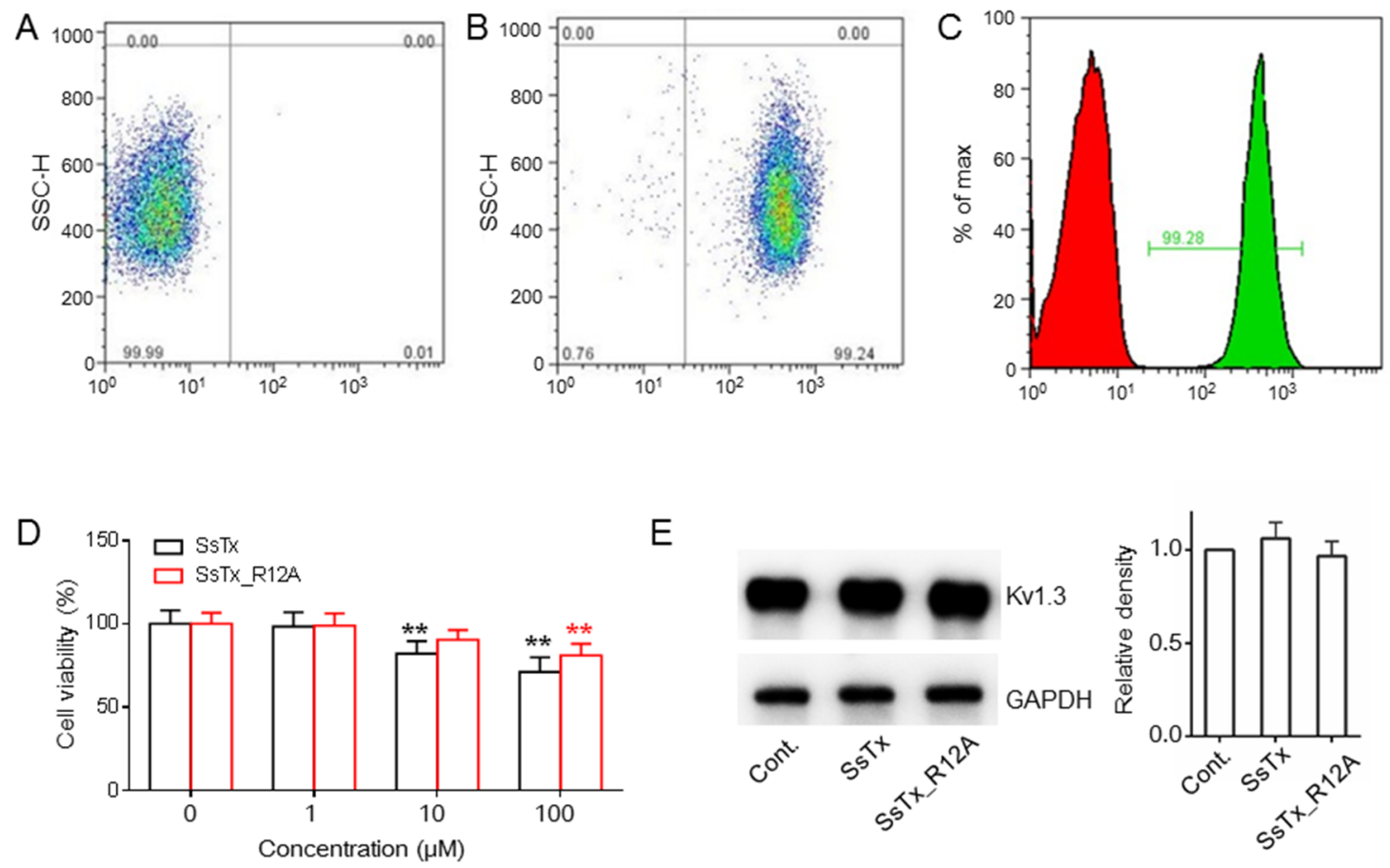

Figure 3. SsTx and SsTx_R12A suppressed proliferation of human T cells without affecting the expression of $K_{V}$ 1.3. (A,B) Isolation of human $T$ cells that were incubated with the primary antibody against CD3+ (B) compared to saline solution (A); SSC-H, side scatter-height. (C)The purity of CD3+ T cells was determined by flow cytometry. (D) The effect of different concentrations of SsTx_R12A on human CD3+ T cell proliferation compared to the absence of SsTx. ${ }^{* *} p<0.01$. (E) Both SsTx and SsTx_R12A at $100 \mu \mathrm{M}$ exerted no significant effect on the expression of $K_{V} 1.3$ on human CD3+ T cells (left panel). The densities of $\mathrm{K}_{\mathrm{V}} 1.3$ were quantified by band intensity with ImageJ relative to GAPDH (glyceraldehyde-3-phosphate dehydrogenase) $(n=3)$ and GAPDH was used as a loading control (right panel).

\subsection{SsTx and Mutant SsTx_R12A Suppress Cytokine Production in T Cells}

Blockage of $\mathrm{K}_{\mathrm{V}} 1.3$ in Tem-effector cells has been reported to suppress the secretion of cytokines, such as TNF- $\alpha$ and IL-2 [21]. Consistent with these observations, both SsTx and mutant SsTx_R12A suppressed the secretion of TNF- $\alpha$ and IL-2 by almost 30\% in activated human CD3+ T cells at a concentration of $10 \mu \mathrm{M}$ (Figure 4A,B). Similarly, SsTx suppressed the production of other cytokines, such as IL-8, IL-17, TFN- $\gamma$, and IL-22, in a concentration-dependent manner (Figure 4C-F). Here, we found that SsTx as the first $\mathrm{K}_{\mathrm{V}} 1.3$ inhibitor from centipede venom not only suppressed Tem-effector cells proliferation but also suppressed the production of cytokines in activated human CD3+ $\mathrm{T}$ cells. This suggests that the mutant SsTx_R12A, by losing its inhibitory activity against $\mathrm{K}_{\mathrm{V}} 7.4$ but maintaining the activity to $K_{V} 1.3$, might be a potential drug for curing autoimmunity diseases. 

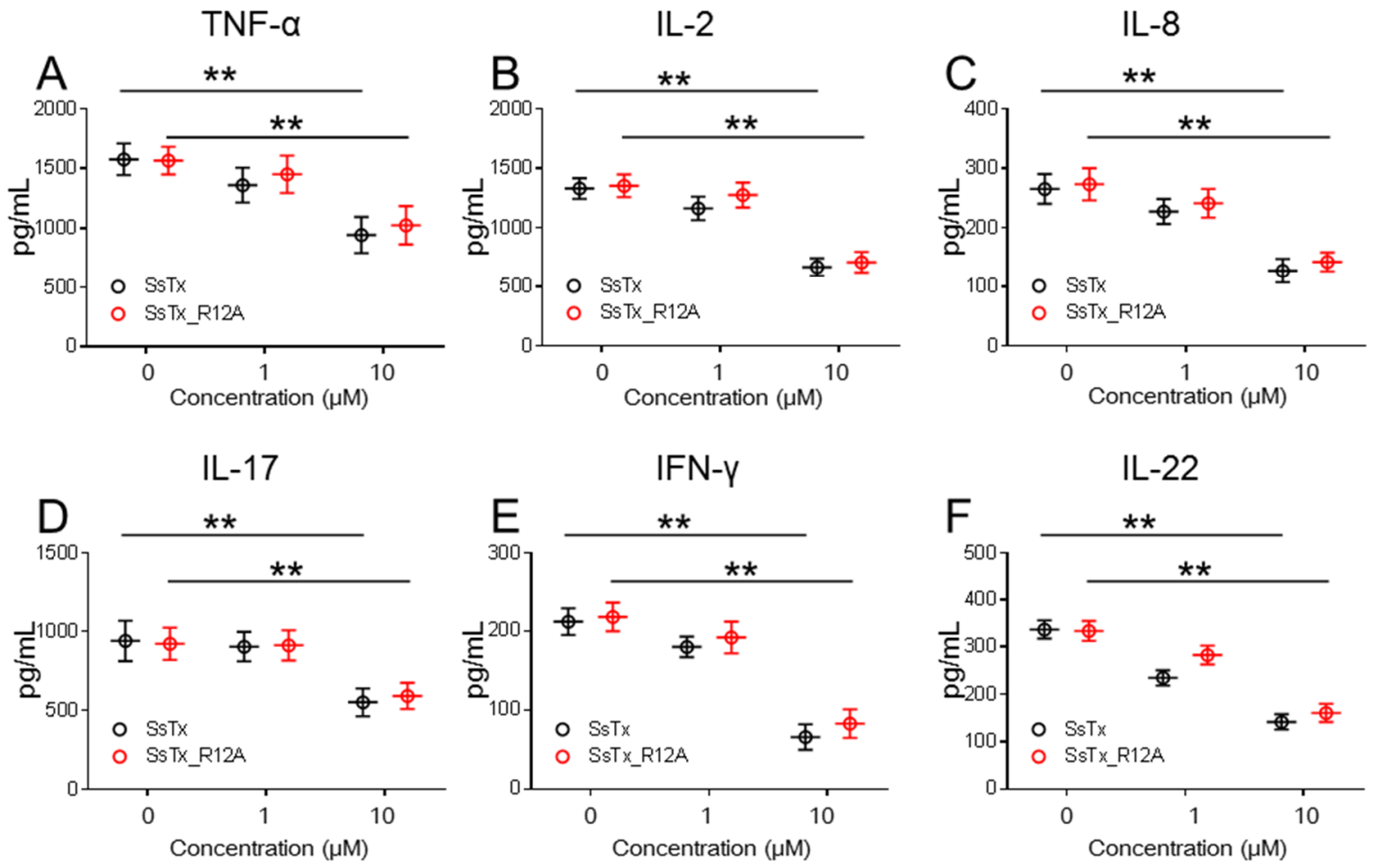

Figure 4. SsTx and SsTx_R12A inhibited the function of human T cells. SsTx and SsTx_R12A inhibited secretion of TNF- $\alpha$ (A), IL-2 (B), IL-8 (C), IL-17 (D), IFN- $\gamma(\mathbf{E})$, and IL-22 (F) in human CD3+ T cells. ** $p<0.01$.

\section{Discussion}

Until recently, the toxins arsenal of centipedes remained elusive [22], with only a few individual venom components characterized and their function established. Advancements in sequencing and mass spectrometry technologies have given researchers a deeper understanding of the evolutionary process, composition, and possible mechanisms of action of centipede venoms. Although the taxonomical scope of species investigated is still narrow, more studies have established that centipede venom consists of a wide repertoire of toxins possessing novel structural scaffolds. $[5,7,23,24]$. In our previous studies, among all identified centipede toxins, we established the physiological importance of SsTx in Chinese red-headed centipede venom [8], specifically its involvement in the induction of severe clinical symptoms following centipede envenomation [25-28].

In this study, we found that the SsTx exhibited potent inhibitory activity on $\mathrm{K}_{\mathrm{V}} 1.3$ (Figure 1). The selective blockage of $\mathrm{K}_{\mathrm{V}} 1.3$ has been established as a viable option for targeting $\mathrm{T}$ cell-mediated autoimmune diseases without inducing generalized immune suppression [29-31]. Nonetheless, side-effects are often observed in toxin-derived potential therapeutics because of off-targets. Interestingly, R12 in SsTx is crucial for anchoring it onto $\mathrm{K}_{\mathrm{V}} 7$ channels whereas $\mathrm{K} 11$ functions in a similar way for binding $\mathrm{K}_{\mathrm{V}} 1.3$ (Figure $2 \mathrm{C}, \mathrm{F}$ ). Taking advantage of the retained affinity to $\mathrm{K}_{\mathrm{V}} 1.3$, we predicted and validated the therapeutic potential of SsTx for autoimmune diseases by suppressing T-cell cytokines production (Figure 4A-F). Our findings on the mutant toxin not only demonstrate a representative method for abolishing toxicity but also present SsTx_R12A and its modified variants as excellent potential therapeutic agents for $\mathrm{T}$ cell-mediated autoimmune diseases.

Animal venom is an important bio-resource library, and several peptides, such as SHK-186 [20] from the sea snail, have been used to explore the relationship between ion channels and certain diseases. SsTx plays an important part for the centipede in preying food and defense against predators by inhibiting $K_{V} 7$ [8]. Here, we have found SsTx showed a dual function, including its ability to inhibit 
$\mathrm{K}_{\mathrm{V}}$ 1.3. Peptides derived from animal venom exhibit multiple functions, and with the elimination of the side effects of these peptides, they offer excellent prospects for development of drug agents.

\section{Materials and Methods}

\subsection{Peptides Synthesis and Refolding}

Following a 9-fluorenyl methoxycarbonyl/tert-butyl strategy and HOBt/TBTU/NMM coupling method, linear Sstx and its mutant peptides were synthesized on an automatic peptide synthesizer (PerSeptive Biosystems, Boston, MA, USA) as described in our previous work. Peptides refolding were performed by peptides dissolution in a solution containing $10 \mathrm{mM}$ glutathione and $100 \mathrm{mM}$ oxidized glutathione. The solution was adjusted to $\mathrm{pH} 6.0$, and placed at $28{ }^{\circ} \mathrm{C}$ for $24 \mathrm{~h}$. A method coupling MODLI-TOF mass spectrometry and HPLC techniques were performed to determine the purity of peptides to be higher than $95 \%$.

\subsection{Cell Transfection}

HEK293T and CHO cells were cultured as described in our previous work [32]. The plasmid DNA $(5 \mu \mathrm{L}, 1 \mu \mathrm{g} / \mu \mathrm{L})$ of $\mathrm{K}_{\mathrm{V}} 1.3$ and $\mathrm{K}_{\mathrm{V}} 7.4$ channel was mixed with lipofectamine at a ratio of 1:1 in $200 \mu \mathrm{L}$ Opti-MEM for 15-20 min, and the mixture was transferred to the cells plated in $20 \mathrm{~mm}$ cell culture dish for $12 \mathrm{~h}$. After $24 \mathrm{~h}$ transfections, electrophysiological experiments were carried out at room temperature.

\subsection{Electrophysiological Recordings}

The cells expressing $\mathrm{K}_{\mathrm{V}} 1.3$ and $\mathrm{K}_{\mathrm{V}} 7.4$ were digested and plated on glass coverslips before current recording. The HEKA EPC10 amplifier (HEKA Elektronik, Ludwigshafen, Germany) was used to record currents in whole cells under the control of PATCHMASTER software (HEKA Elektronik, Ludwigshafen, Germany). A thin-wall borosilicate glass (A-M Systems) was used to pull patch pipettes and then the pipettes were fire-polished to 3-4 megohm. For whole-cell recordings, the capacity current was minimized by amplifier circuitry, and the series resistance was compensated by $30 \%$ to $65 \%$. For $\mathrm{K}_{\mathrm{V}} 1.3$ and $\mathrm{K}_{\mathrm{V}} 7.4$ channel, intracellular solution contained $140 \mathrm{mM} \mathrm{KCl}, 10 \mathrm{mM}$ EGTA, $2 \mathrm{mM}$ $\mathrm{MgCl}_{2}, 1 \mathrm{mM} \mathrm{CaCl}_{2}, 10 \mathrm{mM}$ HEPES ( $\mathrm{pH} 7.3$, adjusted with $\mathrm{KOH}$ ), and extracellular solution contained $150 \mathrm{mM} \mathrm{NaCl}, 0.5 \mathrm{mM} \mathrm{CaCl}_{2}, 5 \mathrm{mM} \mathrm{KCl}, 1.2 \mathrm{mM} \mathrm{MgCl}_{2}, 10 \mathrm{mM}$ HEPES (pH 7.3, adjusted with $\mathrm{NaOH}$ ), and the current traces were tested by a 1000-ms depolarizing pulse of $10 \mathrm{mV}$ from a holding voltage of $-80 \mathrm{mV}$. The Hill logistic equation shown below was used to fit the Dose-response curves:

$$
\mathrm{y}=1-(1-\mathrm{fmax}) /\left[1+\left([\mathrm{Tx}] / \mathrm{IC}_{50}\right) \mathrm{n}\right]
$$

where $\mathrm{n}$ is an empirical Hill coefficient, and fmax is the fraction of current resistant to inhibition at high toxin $(\mathrm{Tx})$ concentration.

\subsection{Human T Cells Isolation}

Peripheral blood mononuclear cells (PBMCs) were collected from healthy volunteers and T cells were isolated from PBMCs by negative magnetic depletion using biotin-conjugated CD14, CD15, CD16, CD19, CD34, CD56, CD123, and CD235a following the manufacturer's instructions of Human Pan T Cells Isolation Kit (Miltenyi Biotec, Bergisch Gladbach, Germany). Ficoll-Hypaque density gradient centrifugation was used to separate the PBMCs at $3000 \mathrm{rpm}$ for 15 min under the manufacturer's protocol. Flow cytometry was carried out to assess the purity of Tem cells to be more than $95 \%$ followed by maintaining in RPMI (Roswell Park Memorial Institute) 1640 medium (Thermo, Waltham, MA, USA) containing 10\% FBS (fetal bovine serum) (Thermo, Waltham, MA, USA), streptomycin $(100 \mu \mathrm{g} / \mathrm{mL})$ and penicillin $(100 \mathrm{U} / \mathrm{mL})$ in $5 \% \mathrm{CO}_{2}$ at $37^{\circ} \mathrm{C}$ for $1 \mathrm{~h}$. 


\subsection{Human T Cells Proliferation and Viability Measurement}

Human T cells obtained as described above were seeded into 96-well plate. $20 \mu \mathrm{L}$ of the test sample dissolved in RPMI 1640 medium was added to the wells followed by $24 \mathrm{~h}$ incubation at $37^{\circ} \mathrm{C}$; the same volume of the medium was used as blank control. After incubation, the medium was replaced with MTT (methyl thiazolyl tetrazolim) containing medium (final concentration $5 \mathrm{mg} / \mathrm{mL}$ ) followed by further incubation for $5 \mathrm{~h}$ under the same conditions. Subsequently, the MTT was dissolved with $200 \mu \mathrm{L}$ dimethyl sulphoxide (DMSO), and then the absorbance of the resulting solution was read at $570 \mathrm{~nm}$. The corresponding cell viability of the treated group was expressed as the percentage viability of the control group.

\section{6. $K_{V} 1.3$ Expression in $T$ Cells}

Cellular proteins $(20 \mu \mathrm{L}, 1 \mathrm{mg} / \mathrm{mL})$ from differently treated groups were loaded onto a $12 \%$ SDS-PAGE gel. After gel electrophoresis at $120 \mathrm{~V}$ for $2 \mathrm{~h}$ at room temperature, the proteins were transferred onto a PVDF (polyvinylidene fluoride) membrane. The membrane was incubated with a 1:500 dilution of a primary antibody against GAPDH and $\mathrm{K}_{\mathrm{V}} 1.3$ (Abcam) at $2-8{ }^{\circ} \mathrm{C}$ for $12 \mathrm{~h}$ after blocking in $5 \%$ skim milk for $1-2 \mathrm{~h}$ at room temperature. The blots were first washed three times with TBST (Tris-Buffer-Solution-Tween) to clean the primary antibody and then incubated with the secondary antibody conjugated by horseradish peroxidase (Abcam) at a 1:1000 dilution. After washing for 3-5 times with TBST, blots development was carried out by chemiluminescence.

\subsection{Cytokines Secretion by Human CD3+T Cells}

SsTx and its mutant were dissolved in PBS and mixed $1 \mathrm{~h}$ before bead stimulation. The dynabeads against $\mathrm{CD} 3+/ \mathrm{CD} 28+$ were used to activate the isolated $\mathrm{CD} 3+\mathrm{T}$ cells for three times at a ratio of 1:1 in 96-well plates. Cells were collected after overnight activation, and cytokines secretion (hTNF- $\alpha$, hIL-2, hIL-8, hIL-17, hIL-22, and hIFN- $\gamma$ ) was determined by ELISA (R\&D, St. paul, MN, USA) under the manufacturer's instructions.

Author Contributions: Conceptualization, R.L. and S.Y.; Methodology, C.D. and S.Y.; Software, C.D.; Validation, C.D., R.L. and S.Y.; Formal analysis, C.D., J.L., and H.T.; Investigation, C.D., J.M. and R.X.; Resources, Z.S. and G.M.; Data curation, R.L. and S.Y.; Writing—original draft preparation, C.D. and S.Y.; Writing—review and editing, R.L.; Visualization, R.L.; Supervision, R.L. and S.Y.; Project administration, R.L. and S.Y.; Funding acquisition, R.L. and S.Y.

Funding: This work was supported by funding from National Science Foundation of China (21761142002), Chinese Academy of Sciences (2015CASEABRI002), Science and technology office of Jiangsu Province (BE2016742, Q0201600440) and Yunnan Province (2015HA023) to R.L., National Science Foundation of China (31770835), Chinese Academy of Sciences ("Light of West China" Program and Youth Innovation Promotion Association) and Yunnan Province (2017FB037 and 2018FA003) to S.Y.

Conflicts of Interest: The authors declare no conflict of interest.

\section{References}

1. Dugon, M.M.; Hayden, L.; Black, A.; Arthur, W. Development of the venom ducts in the centipede scolopendra: An example of recapitulation. Evol. Dev. 2012, 14, 515-521. [CrossRef] [PubMed]

2. Hasan, S.; Hassan, K. Proteinuria associated with centipede bite. Pediatr. Nephrol. 2005, 20, 550-551. [CrossRef] [PubMed]

3. Hakim, M.A.; Yang, S.L.; Lai, R. Centipede venoms and their components: Resources for potential therapeutic applications. Toxins 2015, 7, 4832-4851. [CrossRef] [PubMed]

4. Yang, S.L.; Yang, F.; Wei, N.N.; Hong, J.; Li, B.W.; Luo, L.; Rong, M.Q.; Yarov-Yarovoy, V.; Zheng, J.; Wang, K.W.; et al. A pain-inducing centipede toxin targets the heat activation machinery of nociceptor trpv1. Nat. Commun. 2015, 6, 8297. [CrossRef] [PubMed]

5. Rong, M.Q.; Yang, S.L.; Wen, B.; Mo, G.X.; Kang, D.; Liu, J.; Lin, Z.L.; Jiang, W.B.; Li, B.W.; Du, C.Q.; et al. Peptidomics combined with cdna library unravel the diversity of centipede venom. J. Proteomics 2015, 114, 28-37. [CrossRef] [PubMed] 
6. Yang, S.L.; Xiao, Y.; Kang, D.; Liu, J.; Li, Y.; Undheim, E.A.B.; Klint, J.K.; Rong, M.Q.; Lai, R.; King, G.F. Discovery of a selective $\mathrm{Na}(\mathrm{v}) 1.7$ inhibitor from centipede venom with analgesic efficacy exceeding morphine in rodent pain models. Proc. Natl. Acad. Sci. USA 2013, 110, 17534-17539. [CrossRef] [PubMed]

7. Yang, S.; Liu, Z.H.; Xiao, Y.; Li, Y.; Rong, M.Q.; Liang, S.P.; Zhang, Z.Y.; Yu, H.N.; King, G.F.; Lai, R. Chemical punch packed in venoms makes centipedes excellent predators. Mol. Cell. Proteomics 2012, 11, 640-650. [CrossRef] [PubMed]

8. Luo, L.; Li, B.; Wang, S.; Wu, F.; Wang, X.; Liang, P.; Ombati, R.; Chen, J.; Lu, X.; Cui, J.; et al. Centipedes subdue giant prey by blocking KCNQ channels. Proc. Natl. Acad. Sci. USA 2018, 115, 1646-1651. [CrossRef] [PubMed]

9. Wulff, H.; Calabresi, P.A.; Allie, R.; Yun, S.; Pennington, M.; Beeton, C.; Chandy, K.G. The voltage-gated Kv1.3 K+ channel in effector memory T cells as new target for MS. J. Clin. Investig. 2003, 111, 1703-1713. [CrossRef] [PubMed]

10. Beeton, C.; Pennington, M.W.; Wulff, H.; Singh, S.; Nugent, D.; Crossley, G.; Khaytin, I.; Calabresi, P.A.; Chen, C.Y.; Gutman, G.A.; et al. Targeting effector memory T cells with a selective peptide inhibitor of Kv1.3 channels for therapy of autoimmune diseases. Mol. Pharmacol. 2005, 67, 1369-1381. [CrossRef] [PubMed]

11. Beeton, C.; Wulff, H.; Standifer, N.E.; Azam, P.; Mullen, K.M.; Pennington, M.W.; Kolski-Andreaco, A.; Wei, E.; Grino, A.; Counts, D.R.; et al. Kv1.3 channels are a therapeutic target for T cell-mediated autoimmune diseases. Proc. Natl. Acad. Sci. USA 2006, 103, 17414-17419. [CrossRef] [PubMed]

12. Schmidt, D.; MacKinnon, R. Voltage-dependent K+ channel gating and voltage sensor toxin sensitivity depend on the mechanical state of the lipid membrane. Proc. Natl. Acad. Sci. USA 2008, 105, 19276-19281. [CrossRef] [PubMed]

13. Chen, R.; Robinson, A.; Gordon, D.; Chung, S.H. Modeling the binding of three toxins to the voltage-gated potassium channel (Kv1.3). Biophys. J. 2011, 101, 2652-2660. [CrossRef] [PubMed]

14. Qiu, S.; Yi, H.; Liu, H.; Cao, Z.; Wu, Y.; Li, W. Molecular information of charybdotoxin blockade in the large conductance calcium-activated potassium channel. J. Chem. Inf. Model. 2009, 49, 1831-1838. [CrossRef] [PubMed]

15. Rogowski, R.S.; Collins, J.H.; O’Neill, T.J.; Gustafson, T.A.; Werkman, T.R.; Rogawski, M.A.; Tenenholz, T.C.; Weber, D.J.; Blaustein, M.P. Three new toxins from the scorpion pandinus imperator selectively block certain voltage-gated K+ channels. Mol. Pharmacol. 1996, 50, 1167-1177.

16. Campos, F.V.; Chanda, B.; Beirao, P.S.; Bezanilla, F. Beta-scorpion toxin modifies gating transitions in all four voltage sensors of the sodium channel. J. Gen. Physiol. 2007, 130, 257-268. [CrossRef]

17. Chen, L.; Durr, K.L.; Gouaux, E. X-ray structures of ampa receptor-cone snail toxin complexes illuminate activation mechanism. Science 2014, 345, 1021-1026. [CrossRef]

18. Schmitz, A.; Sankaranarayanan, A.; Azam, P.; Schmidt-Lassen, K.; Homerick, D.; Hansel, W.; Wulff, H. Design of pap-1, a selective small molecule Kv1.3 blocker, for the suppression of effector memory T cells in autoimmune diseases. Mol. Pharmacol. 2005, 68, 1254-1270. [CrossRef]

19. Han, S.; Yi, H.; Yin, S.J.; Chen, Z.Y.; Liu, H.; Cao, Z.J.; Wu, Y.L.; Li, W.X. Structural basis of a potent peptide inhibitor designed for Kv1.3 channel, a therapeutic target of autoimmune disease. J. Biol. Chem. 2008, 283, 19058-19065. [CrossRef]

20. Matheu, M.P.; Beeton, C.; Garcia, A.; Chi, V.; Rangaraju, S.; Safrina, O.; Monaghan, K.; Uemura, M.I.; Li, D.; Pal, S.; et al. Imaging of effector memory $\mathrm{T}$ cells during a delayed-type hypersensitivity reaction and suppression by Kv1.3 channel block. Immunity 2008, 29, 602-614. [CrossRef]

21. Beeton, C.; Wulff, H.; Barbaria, J.; Clot-Faybesse, O.; Pennington, M.; Bernard, D.; Cahalan, M.D.; Chandy, K.G.; Beraud, E. Selective blockade of T lymphocyte $\mathrm{K}(+)$ channels ameliorates experimental autoimmune encephalomyelitis, a model for multiple sclerosis. Proc. Natl. Acad. Sci. USA 2001, 98, 13942-13947. [CrossRef] [PubMed]

22. Undheim, E.A.; King, G.F. On the venom system of centipedes (chilopoda), a neglected group of venomous animals. Toxicon 2011, 57, 512-524. [CrossRef] [PubMed]

23. Undheim, E.A.; Jones, A.; Clauser, K.R.; Holland, J.W.; Pineda, S.S.; King, G.F.; Fry, B.G. Clawing through evolution: Toxin diversification and convergence in the ancient lineage chilopoda (centipedes). Mol. Biol. Evol. 2014, 31, 2124-2148. [CrossRef] [PubMed] 
24. Liu, Z.C.; Zhang, R.; Zhao, F.; Chen, Z.M.; Liu, H.W.; Wang, Y.J.; Jiang, P.; Zhang, Y.; Wu, Y.; Ding, J.P.; et al. Venomic and transcriptomic analysis of centipede scolopendra subspinipes dehaani. J. Proteome Res. 2012, 11, 6197-6212. [CrossRef] [PubMed]

25. Ureyen, C.M.; Arslan, S.; Bas, C.Y. Cardiovascular collapse after myocardial infarction due to centipede bite. Wien. Kiln. Wochenschr. 2015, 127, 577-579. [CrossRef] [PubMed]

26. Veraldi, S.; Cuka, E.; Gaiani, F. Scolopendra bites: A report of two cases and review of the literature. Int. J. Dermatol. 2014, 53, 869-872. [CrossRef] [PubMed]

27. Senthilkumaran, S.; Meenakshisundaram, R.; Michaels, A.D.; Suresh, P.; Thirumalaikolundusubramanian, P. Acute ST-segment elevation myocardial infarction from a centipede bite. J. Cardiovasc. Dis. Res. 2011, 2, 244-246. [CrossRef] [PubMed]

28. Yildiz, A.; Biceroglu, S.; Yakut, N.; Bilir, C.; Akdemir, R.; Akilli, A. Acute myocardial infarction in a young man caused by centipede sting. Emerg. Med. J. 2006, 23, e30. [CrossRef] [PubMed]

29. Lam, J.; Wulff, H. The lymphocyte potassium channels Kv1.3 and Kca3.1 as targets for immunosuppression. Drug Dev. Res. 2011, 72, 573-584. [CrossRef] [PubMed]

30. Upadhyay, S.K.; Eckel-Mahan, K.L.; Mirbolooki, M.R.; Tjong, I.; Griffey, S.M.; Schmunk, G.; Koehne, A.; Halbout, B.; Iadonato, S.; Pedersen, B.; et al. Selective Kv1.3 channel blocker as therapeutic for obesity and insulin resistance. Proc. Natl. Acad. Sci. USA 2013, 110, E2239-E2248. [CrossRef] [PubMed]

31. Xie, Z.; Feng, J.; Yang, W.; Xiang, F.; Yang, F.; Zhao, Y.; Cao, Z.; Li, W.; Chen, Z.; Wu, Y. Human alpha-defensins are immune-related Kv1.3 channel inhibitors: New support for their roles in adaptive immunity. FASEB J. 2015, 29, 4324-4333. [CrossRef] [PubMed]

32. Han, Y.; Li, B.; Yin, T.T.; Xu, C.; Ombati, R.; Luo, L.; Xia, Y.; Xu, L.; Zheng, J.; Zhang, Y.; et al. Molecular mechanism of the tree shrew's insensitivity to spiciness. PLoS Biol. 2018, 16, e2004921. [CrossRef] [PubMed]

(C) 2019 by the authors. Licensee MDPI, Basel, Switzerland. This article is an open access article distributed under the terms and conditions of the Creative Commons Attribution (CC BY) license (http:/ / creativecommons.org/licenses/by/4.0/). 